\title{
SISTEM INFORMASI AKUNTANSI PERSEDIAAN OBAT METODE FIRST IN FIRST OUT (STUDI KASUS: RUMAH SAKIT BHAYANGKARA POLDA LAMPUNG)
}

\author{
Wawan Alakel ${ }^{1)}$, Imam Ahmad ${ }^{2)}$, Eli Budi Santoso ${ }^{3)}$ \\ ${ }^{1,2,3)}$ Sistem Informasi, Universitas Teknokrat Indonesia \\ Jl. H.ZA Pagaralam, No 9-11, Labuhanratu, Bandarlampung \\ Email : yeatull@gmail.com ${ }^{1)}$, imamahmad@teknokrat.ac.id ${ }^{2}$, elibudisantoso@teknokrat.ac.id ${ }^{3)}$
}

\begin{abstract}
Abstrak
Rumah Sakit Bhayangkara Lampung merupakan salah satu jenis Rumah sakit kepolisian umum di negara kesatuan Republik Indonesia yang beralamat Jalan Pramuka No. 88, Rajabasa, Kota Bandar Lampung. Apotek farmasi Rumah Sakit Bhayangkara bergerak di bidang farmasi dengan menjual berbagai jenis obat. Namun, selama ini masalah yang dihadapi pihak apotek proses pencatatan sisa obat dan stok tidak sesuai dengan kondisi persediaan dan masih sangat acakacakan dalam persediaan obat serta lama pelayanan karena kekurangan sumber daya. Sebagai solusi maka dibangunnya sistem persediaan obat pada Rumah Sakit Bhayangkara Lampung. Tujuan dari penelitian menghasilkan sistem informasi akuntansi persediaan obat untuk meningkatkan ketepatan dalam persediaan stok obat. Manfaat dibangunnya sistem ini, memudahkan dalam memberi kebijakan yang tepat dan perlu diambil dari pihak apotek secara sistematis dan menjadikan pencatatan stok secara akurat khusunya di bagian farmasi Rumah Sakit Bhayangkara. Dalam pengembangan sistem menggunakan metode prototype. Tahap perancangan menggunakan pemodelan UML yaitu: use case diagam, activity diagram, sequence diagram dan class diagram dan pembangunan sistem menggunakan bahasa pemograman PHP dan MySQL sebagai database. Berdasarkan hasil pengujian menggunakan model black box testing dengan aspek antarmuka fungsionality admin dan fungsionality apoteker. Maka diperoleh hasil analisis kualitas: aspek functionality admin diperoleh nilai $87 \%$ atau sangat layak; aspek functionality apoteker diperoleh nilai $90 \%$ atau sangat layak; Berdasarkan kelayakan seluruh aspek kualitas maka didapat nilai rata-rata $88 \%$ atau sangat layak. Sehingga sistem informasi layak untuk diterapkan dalam hal memanimalisir terjadinya stok obat yang expired date dan dapat membantu untuk mempermudah mengelola stok obat dan mengelola arus obat dengan akurat.
\end{abstract}

Kata Kunci : Farmasi, Persediaan Obat, Metode Prototype, Metode FIFO, Bhayangkara.

\section{Pendahuluan}

\section{A. Latar Belakang Masalah}

Perkembangan ilmu pengetahuan dan teknologi ini telah mendorong manusia pada kehidupan yang lebih baik, terlebih lagi dengan adanya komputer dimana meningkatkan efisiensi dan kualitas dalam bekerja. Teknologi komputer akan memudahkan penggunanya untuk melakukan pengolahan data yang dapat menghemat waktu dan hasil informasi yang diperoleh akan sangat memuaskan, berguna, dan bermanfaat bagi perusahaan atau instansi yang menggunakannya. Untuk mendapatkan sistem informasi yang dapat digunakan oleh organisasi atau instansi, perlu dilakukan suatu pengembangan (development) sistem informasi secara terus menerus. Berkembangnya teknologi informasi yang demikian pesat sudah merambat ke era digital yaitu informasi yang dahulu masih diolah dengan cara konvensional sekarang telah dikelola dengan teknologi komputer, data yang diolah dan disimpan dalam arsip berupa buku, kini sudah diolah dengan dan disimpan dalam bentuk komputerisasi.

Rumah Sakit Bhayangkara Polda Lampung merupakan salah satu jenis Rumah sakit kepolisian umum di negara kesatuan Republik Indonesia dengan kode RS 1871438 yang pada tanggal 29 Maret 2017 dipimpin oleh direktur dr. M. Faizal Zulkarnaen, Sp. KF. MH.Kes, RSU terselenggara oleh polisi Republik Indonesia, Rumah Sakit Bhayangkara Polda Lampung yang beralamat Jalan Pramuka No. 88, Rajabasa, Kota Bandar Lampung, Provinsi Lampung, Kode Pos 35142, Telpon 706402 Indonesia. Apotek farmasi yang berada di Rumah Sakit Bhayangkara merupakan salah satu bisnis yang bergerak di bidang farmasi dengan menjual berbagai jenis obat.

Penelitian ini dilakukan di Rumah Sakit Bhayangkara Lampung pada bagian Instalasi Farmasi. Dimana dalam pelaksanaan kegiatan, penulis lebih diarahkan untuk melakukan pemeriksaan obat masuk, pemeriksaan obat keluar dan pemeriksaan obat expired yang apabila obat mendekati atau bahkan telah kadaluarsa maka obat tersebut akan dimusnahkan. Dalam hal ini, penulis menemukan permasalahan yang cukup menyulitkan yang dialami oleh pihak apotek yaitu antara pencatatan persediaan obat dan persediaan fisik obat tidak sesuai dan kondisi obat masih sangat berantakan/berserakan serta lamanya pelayanan obat karena kekurangan sumber daya. 
Sebagai solusi atas permasalahan sistem persediaan di Apotik farmasi, maka peneliti akan melakukan perancangan sistem informasi akuntansi persediaan obat sebagai alat bantu untuk memudahkan memberi kebijakan yang tepat dan perlu diambil dari pihak apotek secara sistematis dan menjadikan pencatatan stok secara akurat dan terkomputerisasi.

\section{B. Rumusan Masalah}

Berdasarkan latar belakang, maka penulis mengambil suatu rumusan masalah yaitu: bagaimana merancang dan membangun sistem informasi akuntansi persediaan obat pada bagian farmasi Rumah Sakit Bhayangkara Polda Lampung.

\section{Batasan Masalah}

Penulis membatasi penelitian ini, antara lain:

1. Lokasi penelitian adalah Rumah Sakit Bhayangkara Polda Lampung.

2. Sistem dalam penelitian ini, dapat mengolah data persediaan obat-obatan pada bagian farmasi Rumah Sakit Bhayangkara Polda Lampung.

3. Sistem persediaan obat pada Rumah Sakit Bhayangkara Polda Lampung dibangun menggunakan bahasa pemrograman PHP dan DBMS MySQL sebagai database.

4. Pengembangan sistem informasi persediaan obat Rumah Sakit Bhayangkara Polda Lampung menggunakan model prototype.

5. Pengujian pengujian perangkat lunak yang dibuat, meliputi pengujian desain program tanpa melibatkan kode program (black box testing).

\section{Manfaat Penelitian}

Adapun manfaat dari penelitian yang ingin dicapai, sebagai berikut:

1. Hasil penelitian dapat dijadikan masukan dalam perancangan dan pembagunan sistem informasi akuntansi persediaan obat pada Rumah Sakit Bhayangkara Polda Lampung.

2. Hasil penelitian dapat memudahkan admin dalam melakukan pengolahan data stok obat-obatan pada Rumah Sakit Bhayangkara Polda Lampung dan memudahkan admin dalam melakukan pengawasan pada aktifitas pengolahan persediaan obat masuk dan obat keluar yang berlangsung.

3. Hasil penelitian dapat memudahkan apoteker dalam melihat laporan harian, bulanan atau tahunan mengenai obat masuk dan obat keluar stok obatobatan pada Rumah Sakit Bhayangkara Polda Lampung.

\section{E. Tujuan Penelitian}

Tujuan penelitian sistem informasi akuntansi persediaan obat pada Rumah Sakit Bhayangkara Polda Lampung, sebagai berikut:

1. Menghasilkan sistem informasi persediaan obat pada Rumah Sakit Bhayangkara Polda Lampung untuk meningkatkan ketepatan dalam persediaan stok obat.
2. Mengembangkan sistem yang mampu membantu proses pencatatan stok obat pada bagian farmasi Rumah Sakit Bhayangkara Polda Lampung.

\section{F. Tinjauan Pustaka}

1. Oleh (Palupi, 2015) meneliti tentang Sistem Informasi Akuntansi Persediaan Obat Dengan Metode FIFO (Studi Kasus: De Kosmo Factory Outlet). De Kosmo Factory Outlet merupakan perusahaan yang bergerak dibidang perdagangan pakaian.

2. Oleh (Kristinugraini \& Rubhyanti, 2014) meneliti tentang Sistem Informasi Inventory Obat Menggunakan Metode FIFO Pada Apotek Mugi Waras Semarang Berbasis Clien Server.

3. Oleh (Aprilliyawati et al., 2015) meneliti tentang Sistem Informasi Persediaan Obat Secara Multiuser Pada Apotek Sarwo Sehat Karanganyar.

4. Oleh (Nur, 2017) meneliti tentang Perancangan Dan Implementasi Aplikasi Manajemen Stok Obat Menggunakan Metode FIFO (First In First Out).

5. Oleh (Pranggono et al., 2016) meneliti tentang Sistem Informasi Persediaan Obat Secara Multiuser Pada Apotek Kinasih Bulu Sukoharjo Dengan Metode Rata-rata Bergerak.

\section{G.Landasan Teori}

\section{1) Pengertian Sistem Informasi}

Sistem informasi adalah suatu didalam suatu organisasi yang mempertemukan kebutuhan pengolahan transaksi harian yang mendukung fungsi operasi organisasi yang bersifat manajerial dengan kegiatan strategi dari suatu organisasi untuk dapat menyediakan kepada pihak luar tertentu dengan laporan-laporan yang diperlukan (Sutabri, 2012).

Sistem informasi adalah sekumpulan prosedur organisasi yang pada saat dilaksanakan akan memberikan informasi bagi pengambil keputusan dan untuk mengendalikan organisasi (Ladjamudin, 2005).

Memuat pernyataan di atas penulis menyimpulkan bahwa sistem informasi merupakan penerapan sistem didalam organisasi untuk mendukung informasi yang dibutuhkan oleh semua tingkat manajemen (Ladjamudin, 2005)

\section{2) Pengertian Persediaan}

Persediaan (inventory) didefinisikan sebagai barang dagang yang disimpan oleh perusahaan untuk dijual kepada pelanggan (Horngren \& Harrison, 2007).

Persediaan merupakan aktiva yang tersedia untuk dijual dalam kegiatan usaha normal perusahaan, aktiva dalam proses produksi dan atau dalam perjalanan atau dalam bentuk bahan untuk digunakan dalam proses poduksi atau pemberian jasa, persediaan juga meliputi barang yang dibeli dan disimpan untuk dijual kembali (Mulya, 2013).

Persediaan merupakan suatu aktiva yang meliputi barang-barang milik perusahaan dengan maksud untuk dijual dalam suatu periode usaha tertentu, atau 
persediaan barang-barang yang masih dalam pengerjaan atau proses produksi, ataupun persediaan bahan baku yang menunggu penggunaannya dalam suatu proses produksi (Rangkuti, 2005).

Persediaan pada umumnya merupakan salah satu jenis aktiva lancar yang jumlahnya cukup besar dalam suatu perusahaan. Hal ini mudah dipahami karena persediaan merupakan faktor penting dalam menentukan kelancaran operasi perusahaan. Ditinjau dari segi persediaan adalah barang-barang atau bahan yang masih tersisa, atau barang-barang yang akan segera dijual, digunakan atau diproses dalam periode normal perusahaan (Sartono, 2010).

\section{3) Metode Pengembangan}

Dalam melakukan perancangan sistem yang akan dikembangkan dapat mengunakan Metode Prototype. Metode ini cocok digunakan untuk mengembangkan sebuah perangkat yang akan dikembangkan kembali. Metode ini dimulai dengan pengumpulan kebutuhan pengguna, dalam hal ini pengguna dari perangkat yang dikembangkan adalah peserta didik. Kemudian membuat sebuah rancangan yang selanjutnya akan dievaluasi kembali sebelum diproduksi secara benar (Pressman, 2012)

Metode Prototype bukanlah merupakan sesuatu yang lengkap, tetapi sesuatu yang harus dievaluasi dan dimodifikasi kembali. Segala perubahan dapat terjadi pada saat prototype dibuat untuk memenuhi kebutuhan pengguna dan pada saat yang sama memungkinkan pengembang untuk lebih memahami kebutuhan pengguna secara lebih baik (Pressman, 2012).

Berikut adalah tahapan dalam metode prototype :

1. Komunikasi dan pengumpulan data awal,yaitu analisis terhadap kebutuhan pengguna.

2. Quick design (desain cepat), yaitu pembuatan desain secara umum untuk selanjutnya dikembangkan kembali.

3. Pembentukan prototype, yaitu pembuatan perangkat prototype termasuk pengujian dan penyempurnaan.

4. Evaluasi terhadap prototype, yaitu mengevaluasi prototype dan memperhalus analisis terhadap kebutuhan pengguna.

5. Perbaikan prototype, yaitu pembuatan tipe yang sebenarnya berdasarkan hasil dari evaluasi prototype.

6. Produksi akhir, yaitu memproduksi perangkat secara benar sehingga dapat digunakan oleh pengguna.

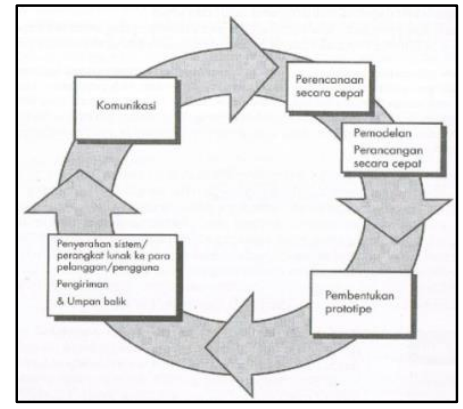

Gambar 1 Paradigma Pembuatan Prototype

\section{4) Metode First In First Out (FIFO)}

First In First Out (FIFO) adalah metode penilaian persediaan yang menganggap barang yang pertama kali masuk diasumsikan keluar pertama kali pula. Pada umumnya perusahaan menggunakan metode ini, sebab metode ini perhitungannya sangat sederhana baik sistem fisik maupun sistem perpetual akan menghasilkan penilaian persediaan yang sama (Syakur, 2009).

Metode First In First Out (FIFO) mengasumsikan bahwa barang dagangan yang pertama dibeli adalah barang dagangan yang pertama dijual (the first merchandise purchased is the first merchandise sold) karena harga pokok penjualan dinilai berdasarkan harga pokok persediaan pertama masuk maka harga pokok persediaan yang tersisa terdiri dari harga pokok persediaan yang terakhir masuk (Syakur, 2009).

Salah satu tujuan dari FIFO adalah menyamakan arus fisik barang, dan berikut keunggulan dari metode FIFO adalah :

1. Perusahaan tidak dapat memanipulasi laba.

2. Mendekatkan nilai persediaan akhir dengan biaya berjalan.

3. umumnya menghasilkan nilai persediaan akhir di neraca yang mendekati biaya pengganti jika tidak terjadi perubahan harga sejak pembelian paling akhir.

Selain itu, metode FIFO banyak digunakan oleh perusahaan-perusahaan karena (Syakur, 2009):

1. Perhitungan dan pelaksanaannya sederhana.

2. Nilai persediaan akhir pada neraca sesuai dengan harga yang berlaku sekarang.

3. Dapat menghindari kerusakan dan keusangan persediaan barang.

\section{5) ХАМРP}

XAMPP adalah paket program web lengkap yang dapat dipakai untuk belajar pemograman web, khususnya PHP dan MySQL. XAMPP adalah perangkat lunak bebas, yang mendukung banyak sistem operasi, merupakan kompilasi dari beberapa program. Fungsinya adalah sebagai server yang berdiri sendiri (localhost), yang terdiri atas program Apache HTTP Server, MySQL database, dan penerjemah bahasa yang ditulis dengan bahasa pemrograman PHP dan Perl (Nugroho, 2013).

Bagian penting dari XAMPP yang diasa digunakan:

1. htdoc adalah folder tempat meletakkan berkas-berkas yang akan dijalankan, seperti berkas PHP, HTML dan skrip lain.

2. PhpMyAdmin merupakan bagian untuk mengelola basis data MySQL yang ada dikomputer. Untuk membukanya, buka browser lalu ketikkan alamat http://localhost/phpMyAdmin, maka akan muncul halaman phpMyAdmin.

3. Kontrol panel yang berfungsi untuk mengelola layanan (service) XAMPP. Seperti menghentikan (stop) layanan, ataupun memulai (start). 


\section{6) Web Server Apache}

Apache merupakan aplikasi web server. Tugas utama apache adalah menghasilkan halaman web yang benar kepada user berdasarkan kode PHP yang dituliskan oleh pembuat halaman web (Nugroho, 2013).

\section{7) MySQL}

MySQL adalah software atau program database server. Sedangkan SQL adalah bahasa pemrogramannya, bahasa permintaan (query) dalam database server termasuk dalam MySQL itu sendiri. SQL juga dipakai dalam software database server lain, seperti SQL Server, Oracle, PostgreSQL dan lainnya (Nugroho, 2013).

\section{8) PhpMyAdmin}

PhpMyAdmin adalah aplikasi manajemen database server MySQL berbasis web. Dengan aplikasi phpMyAdmin kita bias mengelola database sebagai root (pemilik server) atau juga sebagai user biasa, kita bisa membuat database baru, mengelola database dan melakukan operasi perintah-perintah database secara lengkap. phpMyAdmin adalah interface web yang dibuat untuk mengelola database MySQL. phpMyAdmin dibuat menggunakan bahasa PHP dan bersifat open source (Nugroho, 2013).

Dengan phpMyAdmin, administrator web server bisa mengelola database tanpa harus menguasai perintah berbasis baris teks (command line) dari SQL (Structure Query Language). Phpmyadmin sering digunakan pengembang web untuk menyiapkan database dari aplikasi web seperti CMS, Blog dsb (Nugroho, 2013).

Beberapa fitur penting dari phpMyAdmin antara lain:

1. membuat, menghapus dang mengedit baik database, tabel, record, struktur.

2. Membuat pencarian sederhana dan kompleks

3. Import CVS (bisa digunakan untuk menimport data spreedsheet)

4. Eksport ke CVS, XML, Pdf, spreedsheet.

\section{9) Hypertext Markup Language (HTML)}

Hypertext Markup Language (HTML) merupakan bahasa dasar yang digunakan untuk menyusun halaman web. Keberadaannya tetap diperlukan walaupun muncul bahasa seperti PHP ataupun JSP. PHP dan HTML dipakai secara bersama-sama. Dalam hal ini, posisi skrip PHP adalah melekat pada dokumen HTML. Dengan demikian, di dokumen HTML bisa disisipkan skrip PHP. Namun, konsekuensinya, dokumen HTML harus disimpan dengan ektensi berupa .php (Kadir, 2013). Berikut Struktur dasar dokumen HTML adalah sebagai berikut:

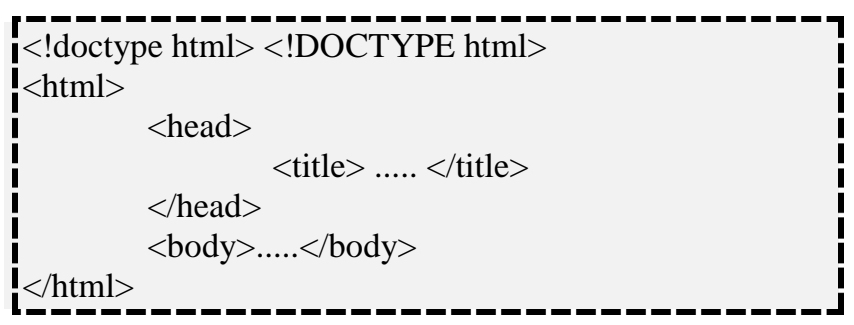

Di dalam dokumen HTML, tanda $<$ menyatakan tag. Tag menyatakan elemen dalam dokumen HTML. Umumnya tag berpasangan. Contoh, <head> berpasangan dengan </head $>$, dan <body $>$ dengan $</$ body $>$. Namun, ada pula tag yang tidak berpasangan. Sebagai contoh, $\langle$ br $>$ dn $\langle$ hr $>$ tidak memiliki pasangan (Kadir, 2013).

Penjelasan untuk tag-tag HTML pada contoh sebagai berikut:

1. Pasangan $<$ html $>$... $</$ html $>$ menyatakan awal dokumen HTML.

2. Di dalam $<$ html $>$... $</$ html $>$ terdapat pasangan $<$ head $>\ldots</$ head $>$ dan $\langle$ body $>\ldots<$ /body $>$.

3. Pasangan $<$ head $>$... $<$ /head $>$ menyatakan bagian judul dokumen HTML. Isinya paling tidak berupa pasangan $<$ title $>$... $<$ title $>$.

4. Isian yang berada pada $\langle$ title $>\ldots</$ title $>$ menentukan judul dalam Browser.

5. Pasangan <body $>$... $<$ body $>$ menyatakan bagian tubuh dokumen. Bagian ini bisa berbagai tag misalnya $\langle$ div $>\ldots</$ div $>$ atau $\langle$ h $1>\ldots</$ h $1>$.

\section{0) Personal Home Page (PHP)}

PHP (Hypertext Preprocessor) itu bahasa pemograman berbasis web. Jadi, PHP itu adalah bahasa program yang digunakan untuk membuat aplikasi berbasis web. PHP termasuk bahasa program yang bisa bisa berjalan di sisi server, atau sering disebut Side Server Language. Jadi, program yang dibuat dengan kode PHP tidak bisa berjalan kecuali dia dijalankan pada server web, tanpa adanya server web yang terus berjalan dia tidak akan bisa dijalankan (Nugroho, 2013).

PHP merupakan bahasa pemrograman yang ditunjuk untuk membuat aplikasi web. Ditinjau dari pemrosesannya, PHP tergolong berbasis server side. Artinya, pemrosesan dilakukan di server. Hal ini berkebalikan dengan bahasa seperti JavaScript, yang pemrosesannya dilakukan di sisi klient (client side). PHP sering dikatakan bahasa untuk membangun aplikasi web dinamis. Pengertian dinamis di sini adalah memungkinkan untuk menampilkan data yang tersimpan dalam database. Dengan demikian, halaman web akan menyesuaikan dengan isi database (Kadir, 2013).

\section{1) Adobe Dreamweaver}

Adobe Dreamwever merupakan suatu perangkat lunak web editor keluaran Adobe Sistem yang digunakan untuk membangun dan mendesain suatu website dengan fiturfitur yang menarik dan kemudahan dalam penggunaannya. Dreamweaver CS6 tergabung dalam paket Adobe Creative Suite (CS) yang di dalamnya terdapat paket desain grafis, video editing, dan pengembangan web aplikasi (Sadeli, 2014).

Pada Dreamweaver CS6 terdapat beberapa fitur baru dari versi sebelumnya seperti Fluid Grid Layout yang dapat mengatur multi halaman web dengan mudah, Web Fonts Manager manajemen yang memungkinkan anda untuk menggunakan font yang tersedia di web server, CSS 
Style Panel tambahan untuk membuat grafis seperti bayangan pada elemen tertentu, gradient, membuat sudut oval dan lain sebagainya, CSS Transitions spesial efek pada elemen, phone GAP memungkinkan anda untuk membangun aplikasi smartphone menjadi lebih mudah dari sebelumnya (Sadeli, 2014).

\section{Pembahasan}

\section{A. Usulan Perancangan Sistem}

\section{1) Use Case Diagram}

Use case diagram merupakan salah satu diagram yang digunakan untuk memodelkan aspek perilaku sistem, use case diagram akan mengambarkan sebuah interaksi antara aktor terhadap sistem. Berikut use case diagram sistem informasi akuntansi persediaan obat dapat dilihat pada gambar 2 di bawah ini.

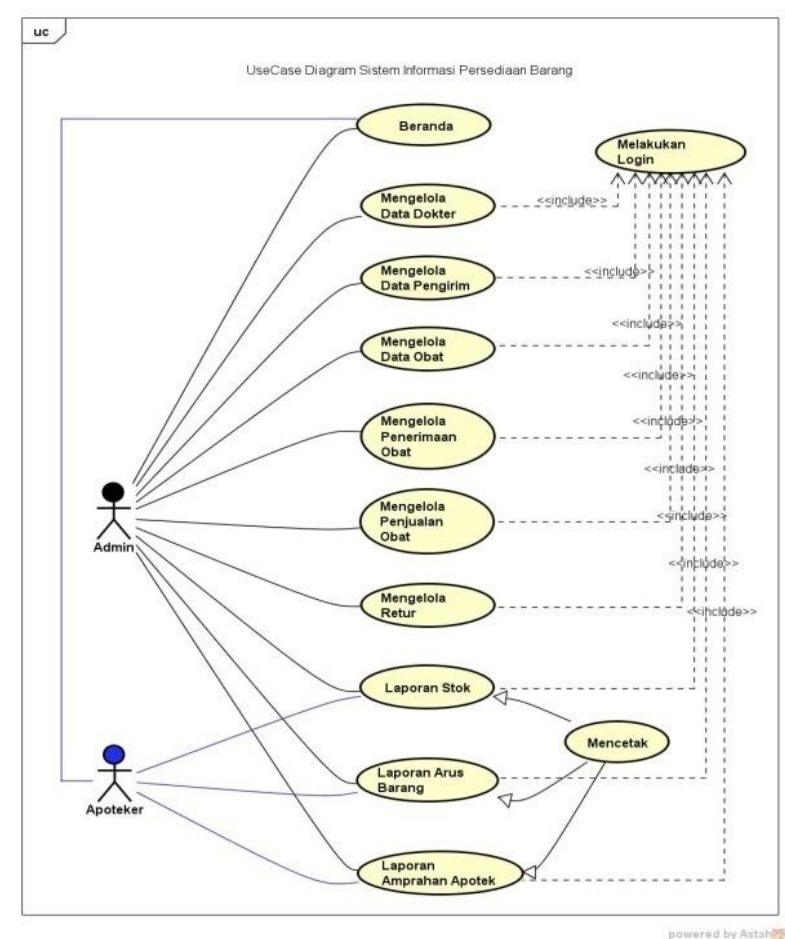

Gambar 2 Use Case Diagram Sistem Informasi Akuntansi Persediaan Obat

\section{2) Class Diagram}

Class diagram merupakan model yang menggambarkan struktur dan deskripsi class serta hubungannya antara class lain. Class diagram menjelaskan model yang digunakan dalam perancangan atribut serta fungsi yang digunakan dalam membangun rancangan sistem baru. Berikut class diagram sistem informasi akuntansi persediaan obat dapat dilihat pada gambar 3 di bawah ini.

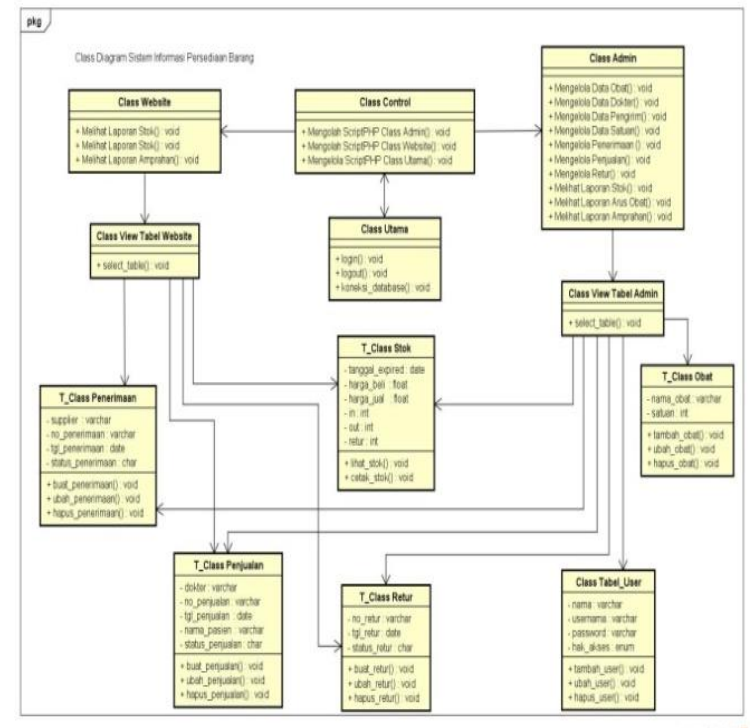

Gambar 3 Class Diagram Sistem Informasi Akuntansi Persediaan Obat

\section{3) Activity Diagram}

Proses yang terjadi didalam use case diagram dari aktivitas yang terjadi didalam sistem yang sedang dirancang, dimulai sampai dengan berhenti digambarkan menggunakan activity diagram. Activity sistem informasi akuntansi persediaan obat menjelaskan proses yang berlangsung dari admin mengelola data kebutuhan website dan user atau apoteker melengkapi data sampai dengan terbentuk laporan persediaan obat. Berikut activity diagram sistem informasi akuntansi persediaan obat dapat dilihat pada gambar 4 di bawah ini.

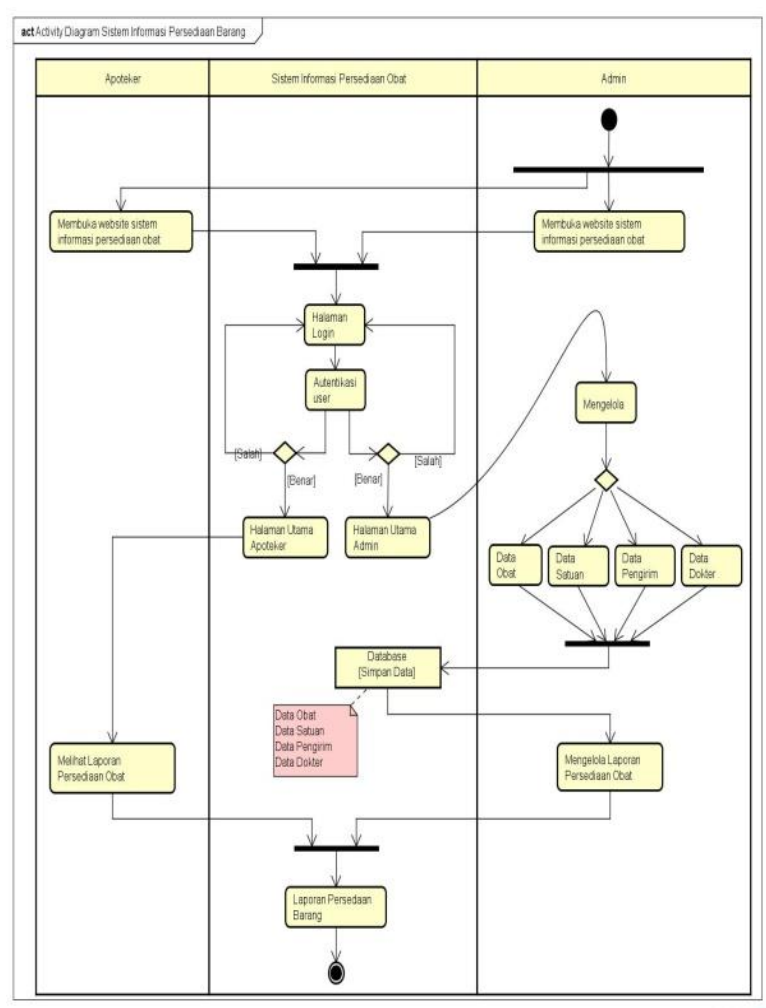

Gambar 4 Activity Diagram Sistem Informasi Akuntansi Persediaan Obat 


\section{4) Sequence Diagram}

Sequence diagram merupakan suatu diagram yang menggambarkan interaksi antar activity diagram dan mengidentifikasikan komunikasi diantara objek yang menunjukkan serangkaian pesan yang dipertukarkan oleh objek-objek yang melakukan suatu tugas atau aksi tertentu. Berikut sequence diagram admin mengelola data obat dapat dilihat pada gambar 5 di bawah ini.

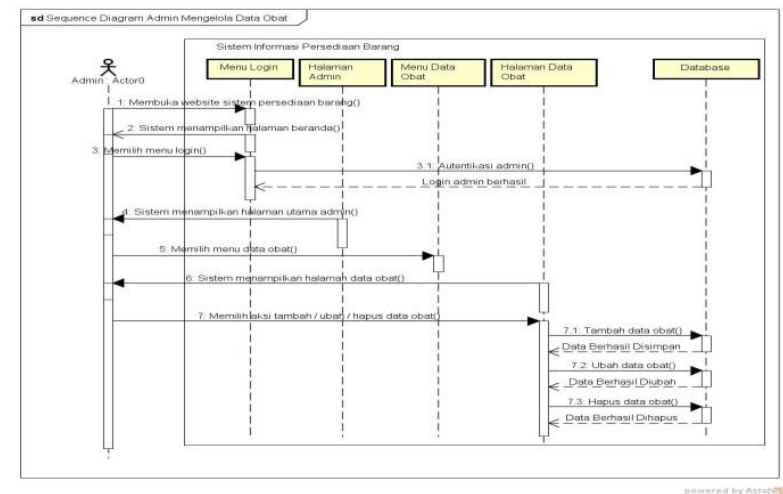

Gambar 5 Sequence Diagram Admin Mengelola Data Obat

Selanjutnya, sequence diagram apoteker melihat laporan persediaan obat dapat dilihat pada gambar 6 di bawah ini.

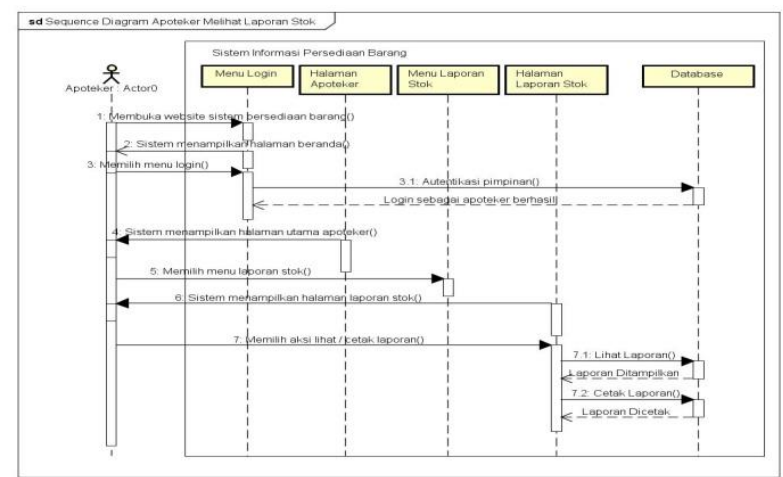

Gambar 6 Sequence Diagram Apoteker Melihat Laporan Persediaan Obat

\section{B. Rancangan Database}

Rancangan database atau basisdata merupakan desain dari field-field pada file yang mendukung basisdata pada rancangan sebuah sistem. Rancangan basisdata dilakukan dengan menggunakan bahasa SQL, dimana DBMS yang digunakan adalah MySQL. Adapun implementasi basis sistem informasi akuntansi persediaan obat pada Rumah Sakit Bhayangkara.

Berikut Spesifikasi Database :

$\begin{array}{ll}\text { Nama DBMS } & \text { : MYSQL } \\ \text { Nama_Database } & \text { : db_apotek } \\ \text { Media_penyimpanan } & \text { : Harddisk }\end{array}$

\section{5) Relasi Antar Tabel}

Berikut relasi tabel yang berhasil berhasil di implementasikan berdasarkan tabel-tabel yang telah dibuat sebelumnya dapat dilihat pada gambar 7 di bawah ini:

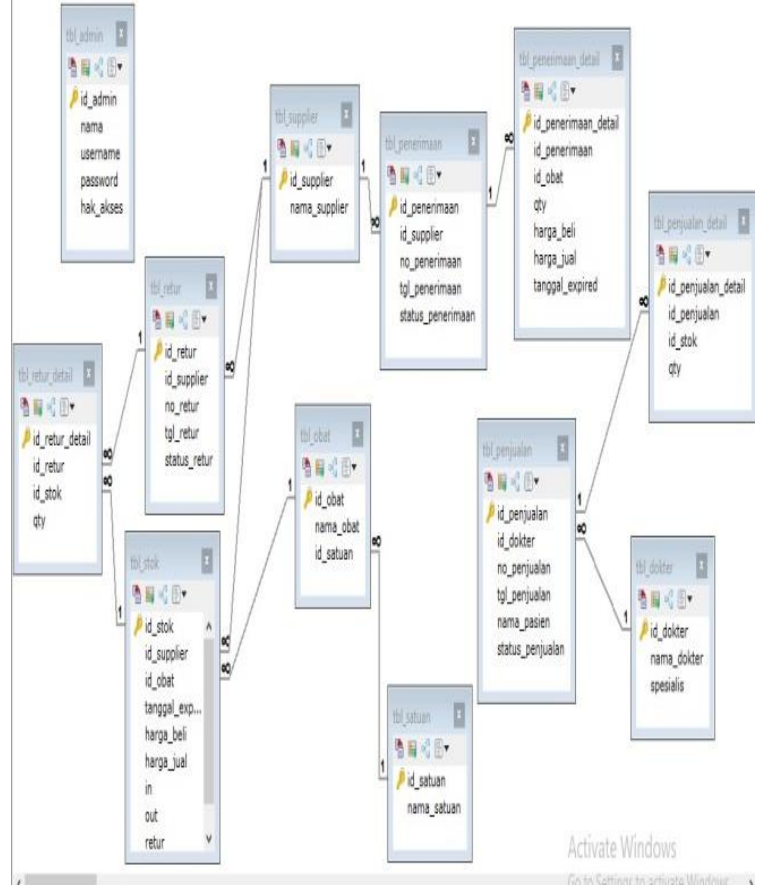

Gambar 7 Relasi Antar Tabel Sistem Informasi Akuntansi Persediaan Obat

\section{Rancangan Desain Antarmuka}

\section{1) Rancangan Form Dashboard Admin}

Rancangan Form Dashboard berisi menu-menu pilihan yang berkaitan dengan penggunaan sistem. Terdapat beberapa komponen menu pada menu utama admin (dashboard) seperti Menu Dashboard, Master Data, Penerimaan, Penjualan, Retur, Laporan dan Ganti Password. Berikut Rancangan Form Dashboard Admin dapat dilihat pada gambar 8 di bawah ini.

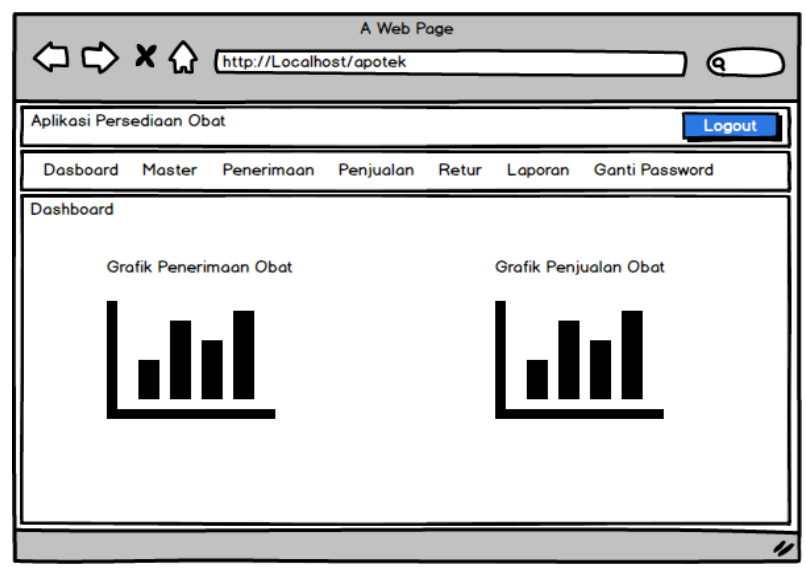

Gambar 8 Rancangan Form Dashboard Admin

\section{2) Rancangan Form Dashboard Apoteker}

Rancangan Form Dashboard berisi menu-menu pilihan yang berkaitan dengan penggunaan sistem. Terdapat beberapa komponen menu pada menu utama apoteker (dashboard) seperti Menu Dashboard, Laporan, Ganti Password. Berikut Rancangan Form Dashboard Apoteker dapat dilihat pada gambar 9 di bawah ini. 


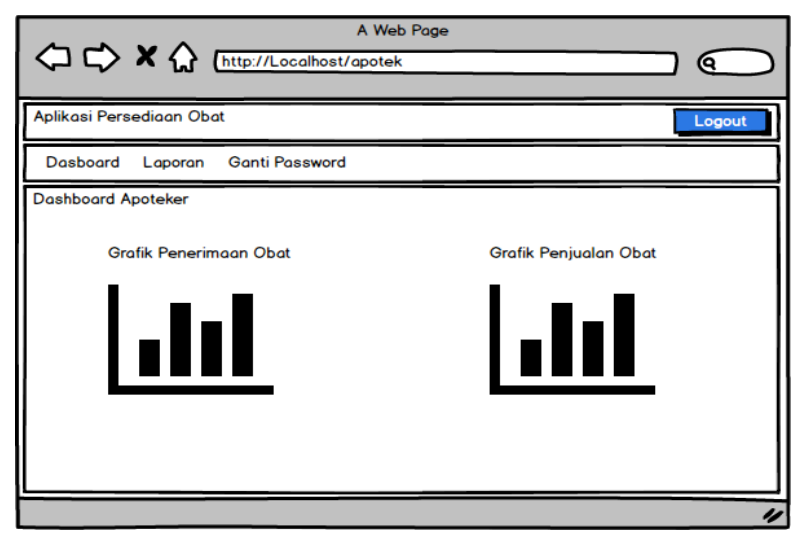

Gambar 9 Rancangan Form Dashboard

\section{3) ApotekerRancangan Form Input Data Obat}

Rancangan Form Input Data Obat berisikan field Nama Obat, Pilihan Satuan dan Aksi yaitu Simpan untuk melakukan proses penyimpanan data kedalam database. Berikut Rancangan Form Input Data Obat dapat dilihat pada gambar 10 di bawah ini.

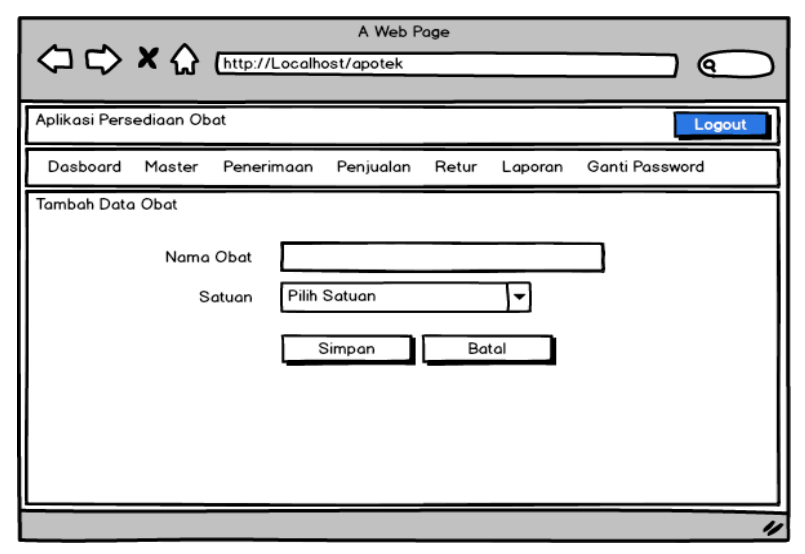

Gambar 10 Rancangan Form Input Data Obat

\section{4) Rancangan Form Laporan Arus Obat}

Rancangan Form Laporan Arus Obat berisikan tabel Penerimaan, tabel Penjualan, tabel Retur dan Aksi Pilihan 'Awal Tanggal', Pilihan 'Akhir Tanggal', Lihat Laporan dan Cetak. Berikut Rancangan Form Laporan Arus Obat dapat dilihat pada gambar 11 di bawah ini.

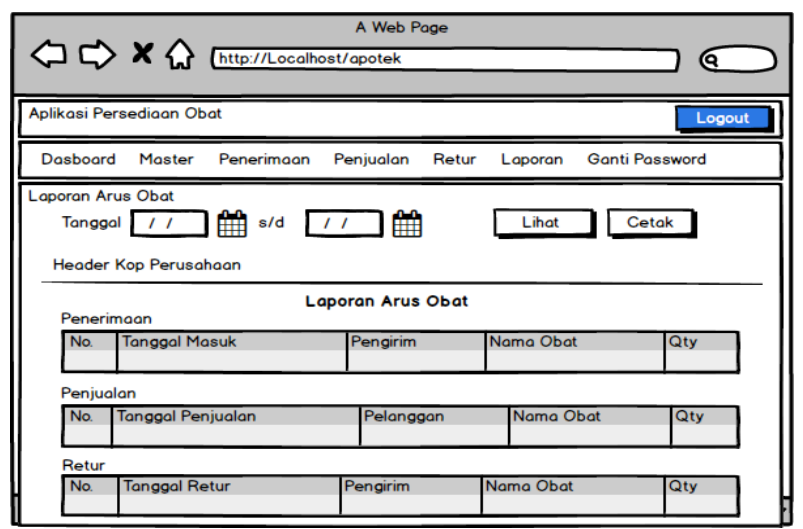

Gambar 11 Rancangan Form Laporan Arus Obat

\section{5) Rancangan Form Laporan Amprahan Apotek}

Rancangan Form Laporan Amprahan Apotek berisikan tabel dengan beberapa field Nama Barang, Satuan, Permintaan, Penerimaan, Harga Satuan (Rp), Jumlah (Rp) dan Aksi Pilihan 'Awal Tanggal', Pilihan 'Akhir Tanggal', Lihat Laporan dan Cetak. Berikut Rancangan Form Laporan Amprahan Apotek dapat dilihat pada gambar 12 di bawah ini.

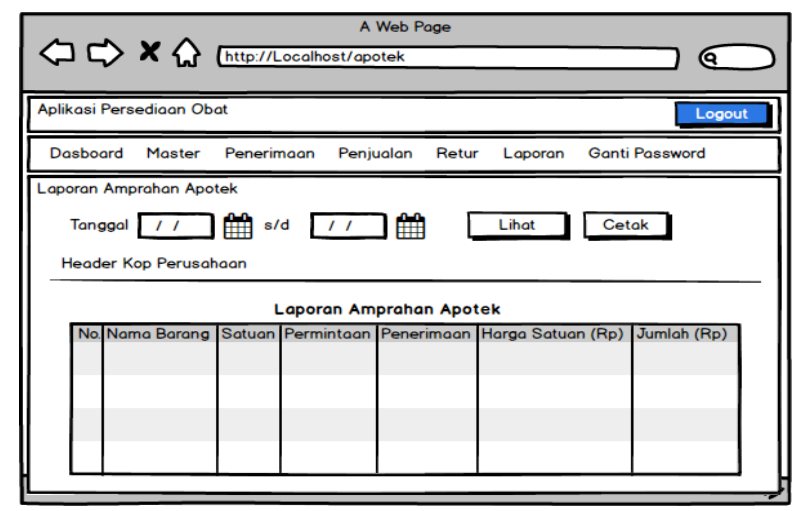

Gambar 12 Rancangan Form Laporan Amprahan Apotek

\section{Implementasi Antar Muka}

\section{1) Implementasi Antarmuka Dashboard Admin}

Halaman Dashboard Admin merupakan tampilan utama admin yang berfungsi untuk mengelola menu atau tampilan lainnya yang terdapat didalam sistem. Tampilan menu utama akan tampil saat admin pertama kali melakukan login. Pada saat halaman ini aktif, admin dapat melakukan setting website melalui menu dan memasukan data atau informasi yang dibutuhkan untuk manajemen website sistem informasi akuntansi persediaan obat pada Rumah Sakit Bhayangkara. Berikut Implementasi Antarmuka Dashboard Admin dapat dilihat pada gambar 13 di bawah ini.

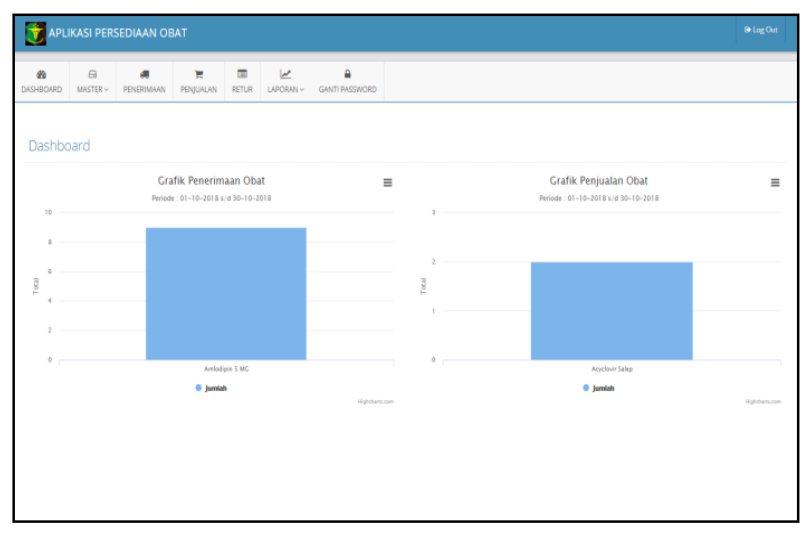

Gambar 13 Implementasi Antarmuka Dashboard Admin

\section{2) Implementasi Antarmuka Dashboard Apoteker}

Halaman Dashboard Apoteker merupakan tampilan utama apoteker yang berfungsi untuk mengelola menu atau tampilan lainnya yang terdapat didalam sistem. Tampilan menu utama akan tampil saat apoteker pertama kali melakukan login. Pada saat halaman ini aktif, apoteker dapat melihat informasi melalui menu dan memasukan data yang terdapat pada website sistem 
informasi akuntansi persediaan obat pada Rumah Sakit Bhayangkara. Berikut Implementasi Antarmuka Dashboard Apoteker dapat dilihat pada gambar 14 di bawah ini.

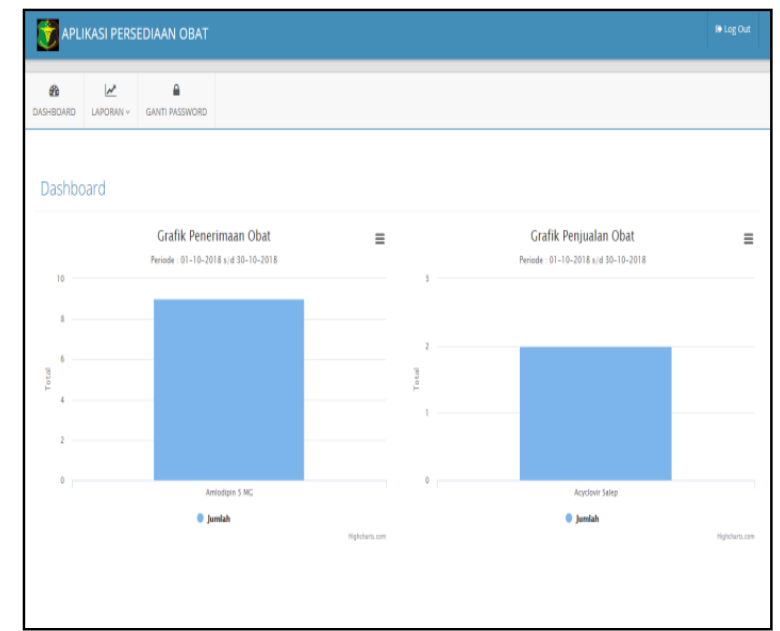

Gambar 14 Implementasi Antarmuka Dashboard Apoteker

\section{3) Implementasi Antarmuka Input Data Obat}

Halaman Input Data Obat akan berfungsi jika Admin menekan Tambah Data pada Halaman Data Obat. Berikut Implementasi Antarmuka Input Data Obat dapat dilihat pada gambar 15 di bawah ini.

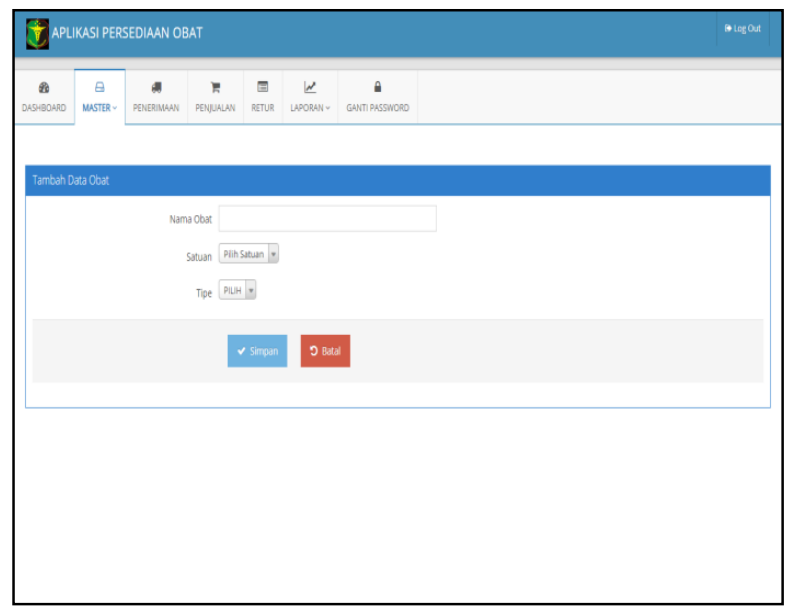

Gambar 15 Implementasi Antarmuka Input Data Obat

\section{4) Implementasi Antarmuka Laporan Arus Obat}

Halaman Laporan Arus Obat merupakan tampilan yang berfungsi untuk admin dalam melihat/memantau arus obat masuk dan arus obat keluar berdasarkan periode tanggal yang diinputkan admin. Berikut Implementasi Antarmuka Laporan Arus Obat dapat dilihat pada gambar 16 di bawah ini.

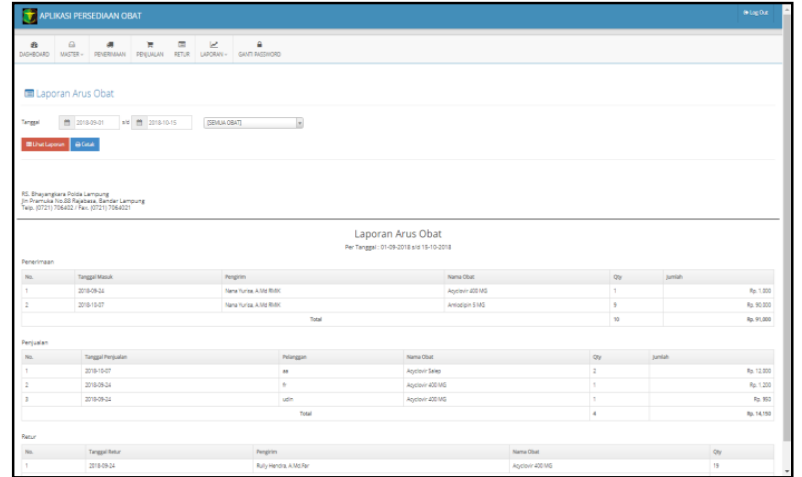

Gambar 16 Implementasi Antarmuka Laporan Arus Obat

\section{5) Implementasi Antarmuka Cetak Laporan Arus} Obat

Halaman Cetak Laporan Arus Obat akan berfungsi jika Admin menekan Cetak pada Halaman Laporan Arus Obat. Berikut Implementasi Antarmuka Cetak Laporan Arus Obat dapat dilihat pada gambar 17 di bawah ini.

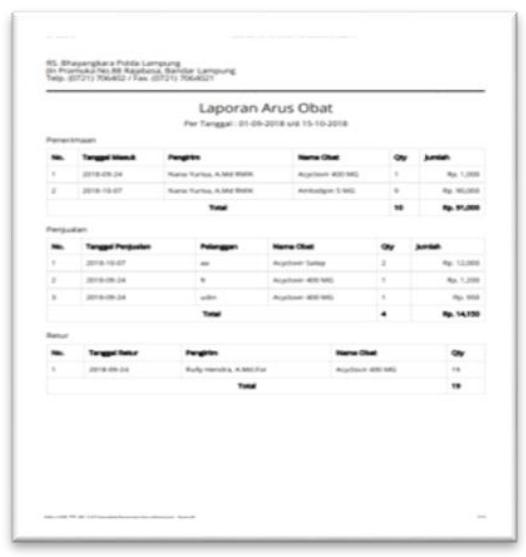

Gambar 17 Implementasi Antarmuka Cetak Laporan Arus Obat

\section{6) Implementasi Antarmuka Laporan Amprahan Apotek}

Halaman Laporan Amprahan Apotek merupakan tampilan yang berfungsi untuk admin dalam melihat/memantau laporan penjualan sehingga terbentuk laporan keuntungan bagi perusahaan berdasarkan periode tanggal yang diinputkan admin. Berikut Implementasi Antarmuka Laporan Amprahan Apotek dapat dilihat pada gambar 18 di bawah ini.

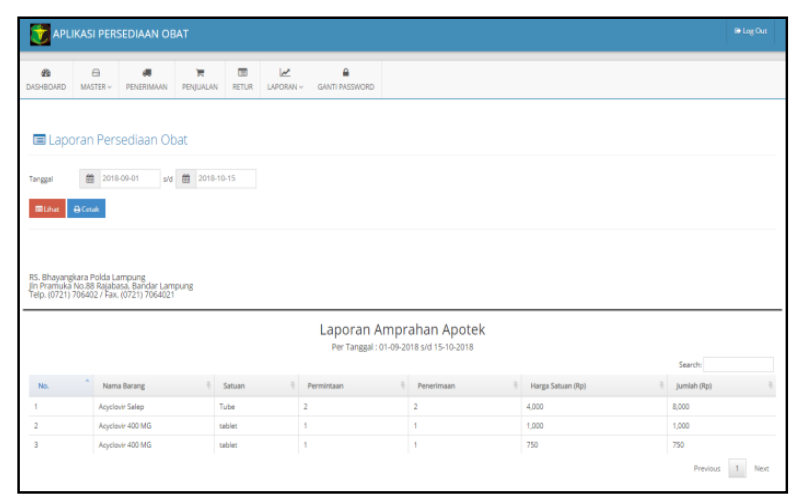


Gambar 18 Implementasi Antarmuka Laporan Amprahan Apotek

\section{7) Implementasi Antarmuka Cetak Laporan Amprahan Apotek}

Halaman Cetak Laporan Amprahan Apotek akan berfungsi jika Admin menekan Cetak pada Halaman Laporan Amprahan Apotek. Berikut Implementasi Antarmuka Cetak Laporan Amprahan Apotek dapat dilihat pada gambar 19 di bawah ini.

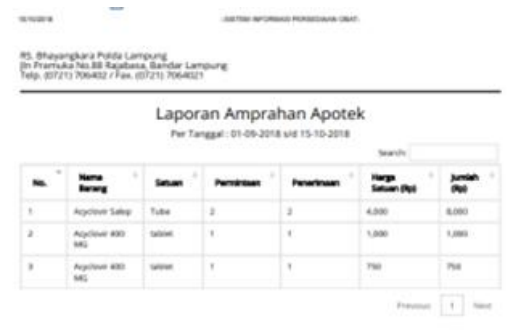

Gambar 19 Implementasi Antarmuka Cetak Laporan Amprahan Apotek

\section{E. Kelayakan Sistem}

Studi kelayakan (feasibility study) merupakan suatu studi yang akan digunakan untuk menentukan kemungkinan apakah pengembangan proyek sistem layak diteruskan atau dihentikan. Studi kelayakan disebut juga dengan istilah high point review (Jogianto, 2008).

Penilaian terhadap kelayakan operasional digunakan untuk mengukur apakah sistem yang akan dikembangkan nantinya dapat dioperasikan dengan baik atau tidak di dalam orgnisasi (Jogianto, 2008).

\section{1) Skala Pengukuran}

Skala pengukuran yang digunakan dapat dilihat pada tabel 1 berikut (Sugiyono, 2011).

Tabel 1 Skala Pengukuran Likert

\begin{tabular}{|l|c|}
\hline \multicolumn{1}{|c|}{ Kategori } & Skor \\
\hline Sangat Setuju & 5 \\
\hline Setuju & 4 \\
\hline Cukup Setuju & 3 \\
\hline Tidak Setuju & 2 \\
\hline Sangat Tidak Setuju & 1 \\
\hline
\end{tabular}

Nilai yang diperoleh dari penghitungan kemudian diubah dalam bentuk persentase (\%). Besarnya persentase dihitung dengan persamaan berikut:

$$
\text { Persentase }=\frac{\text { Nilai yang didapat }}{\text { Nilai maksimal }} \text { X } 100 \%
$$

Gambar 20 Persentase Kelayakan Sistem

Selanjutnya, dari lima kategori atau skor yang ada di tabel 1 dibuat skala kategori kelayakan sistem, pembagian skala ini dilakukan dengan memperhatikan letak rentang bilangan (Arikunto \& Jabar, 2008). Sehingga pada kondisi maksimal yang diharapkan adalah
100\%. Dari kondisi maksimal tersebut dibuat agar tiap kategori memiliki rentang persentase Antara nilai 1\% sampai dengan nilai $100 \%$ dibagi rata sehingga menghasilkan kategori kelayakan sistem seperti tabel 2 berikut.

Tabel 2 Kategori Kelayakan Sistem

\begin{tabular}{|c|c|c|}
\hline No. & Kategori & Skor \\
\hline 1 & Sangat Layak & $81 \%-100 \%$ \\
\hline 2 & Layak & $61 \%-80 \%$ \\
\hline 3 & Cukup Layak & $41 \%-60 \%$ \\
\hline 4 & Tidak Layak & $21 \%-40 \%$ \\
\hline 5 & Sangat Tidak Layak & $-21 \%$ \\
\hline
\end{tabular}

\section{2) Hasil Uji Kelayakan}

Berikut hasil uji kelayakan sistem secara keseluruhan pada sistem informasi persediaan obat Rumah Sakit Bhayangkara dapat dilihat pada tabel 3 di bawah ini.

Tabel 3 Hasil Uji Kelayakan Secara Keseluruhan

\begin{tabular}{|l|c|c|c|c|}
\hline \multicolumn{1}{|c|}{ Aspek } & $\begin{array}{c}\text { Skor } \\
\text { Aktual }\end{array}$ & $\begin{array}{c}\text { Skor } \\
\text { Ideal }\end{array}$ & $\begin{array}{c}\text { Persentase } \\
(\%)\end{array}$ & Interpretasi \\
\hline Fungsional Admin & 113 & 130 & 87 & Sangat Layak \\
\hline Fungsional Apoteker & 108 & 120 & 90 & Sangat Layak \\
\hline Total & 168 & 190 & 88 & Sangat Layak \\
\hline
\end{tabular}

Berdasarkan hasil uji kelayakan sistem yang telah dilakukan, pengujian ini melibatkan 6 responden dengan kesimpulan bahwa kualitas perangkat lunak yang dihasilkan memiliki tingkat yang "Sangat Layak" dan dinilai layak untuk diterapkan pada Rumah Sakit Bhayangkara Lampung, untuk penjabaran kuesioner terkait penelitian yang penulis lakukan dipaparkan di bagian lampiran.

\section{Penutup}

\section{A. Kesimpulan}

Dari hasil pengembangan sistem informasi persediaan obat Rumah Sakit Bhayangkara yang sudah dilakukan, maka dapat ditarik kesimpulan sebagai berikut:

1. Pembangunan sistem informasi dilakukan pada platform berbasis web. Bahasa pemograman yang digunakan dalam pembangunan sistem ini adalah PHP (PHP: Hypertext Preprocessor) dengan Tools Adobe Dreamwever sebagai editor penulisan code PHP dan HTML. Sedangkan disisi manajemen database menggunakan DBMS MySQL dengan Tools SQLYog sebagai front-end untuk mempermudah manajemen database MySQL.

2. Dengan mengimplementasikan metode first in first out (FIFO) maka sistem informasi persediaan obat yang dibuat dapat memanimalisir terjadinya stok obat yang expired date dan dapat membantu untuk mempermudah admin dalam mengelola stok obat, 
mengelola arus obat masuk dan arus obat keluar dengan akurat.

3. Hasil uji kelayakan menunjukkan bahwa sistem informasi persediaan obat telah berhasil diuji menggunakan mengunakan teknik kuesinoer. Selanjutnya penilaian kuesioner di ukur berdasarkan Skala Linkert dan dikonversi berdasarkan kategori kelayakan sistem. Berikut hasil uji kelayakan sistem: (1) aspek fungsional admin diperoleh nilai $87 \%$ atau sangat layak; (2) fungsional apoteker diperoleh nilai $90 \%$ atau sangat layak; Berdasarkan kelayakan seluruh aspek kualitas maka didapat nilai rata-rata $88 \%$ atau sangat layak.

\section{B. Saran}

Dengan sistem ini diharapkan dapat menjadi saran untuk pengembangan sistem lebih lanjut, untuk meningkatkan kinerja pada sistem ini agar lebih baik, maka diharapkan:

1. Diharapkan pemeliharaan data dan informasi obat didalam database sistem informasi senantiasa diperbaharui, sebab akan memberikan arti yang sangat penting terhadap perusahaan.

2. Diharapkan perlu adanya perawatan serta pengembangan sistem untuk dikemudian harinya, sehingga nantinya sistem ini bisa lebih baik lagi dan dapat bermanfaat bagi yang membutuhkan.

Diharapkan untuk meningkatkan kinerja dari sistem disisi laporan keuangan seperti: laporan rugi laba dapat memberikan fitur tersediri untuk mengolah pendapatan, beban usaha dan rincian rugi-laba sehingga sistem dapat memberikan informasi keberhasilan atau kegagalan yang dicapai secara lebih terperinci.

\section{Daftar Pustaka}

Al Fatta, H., 2007. Analisis \& Perancangan Sistem Informasi: Untuk Keunggulan. Yogyakarta: Andi Offset.

Aprilliyawati, E., Hasbi, M. \& Andriani, 2015. Sistem Informasi Persediaan Obat Secara Multiuser Pada Apotik Sarwo Sehat Karanganyar. Jurnal TIKOMSIN, ISSN : 2338-4018 26.

Arikunto, S., 2013. Prosedur Penelitian Suatu Pendekatan Praktik. Jakarta: Rineka Cipta.

Arikunto, S. \& Jabar, C.S.A., 2008. Evaluasi Program Pendidikan: Pedoman Teoritis Praktis Bagi Mahasiswa dan Praktisi Pendidikan Edisi ke-2. Jakarta: Bumi Aksara.

Horngren, C.T. \& Harrison, W.T., 2007. Akuntansi Volume 2. Jakarta: Erlangga.

Jogiyanto, H., 2009. Sistem Teknologi Informasi Edisi 3. Yogyakarta: Andi.

Kadir, A., 2013. Pemrograman Database MySQL Untuk Pemula. Yogyakarta: MediaKom.

Kristinugraini, R. \& Rubhyanti, R., 2014. Sistem Informasi Inventory Obat Menggunakan Metode
Fifo Pada Apotik Mugi Waras Semarang Berbasis Clien Server. Jurnal STEKOM Semarang.

Ladjamudin, A.-B., 2005. Analisis dan Desain Sistem Informasi. Yogyakarta: Graha Ilmu.

Mandala, D.P. \& Dewanto, A., 2017. Uji Kelayakan Sistem Informasi Unit Kesehatan Sekolah Berbasis Website. Jurnal Elinvo (Electronics, Informatics, and Vocational Education), Volume 2, Nomor 2, November 2017.

Mulya, H., 2013. Memahami Akuntansi Dasar (Pendekatan Teknis Siklus Akuntansi). Jakarta: Mitra Wacana Media.

Nugroho, B., 2013. Dasar Pemograman Web PHP MySQL dengan Dreamweaver. Yogyakarta: Gava Media.

Nur, M.S., 2017. Perancangan Dan Implementasi Aplikasi Manajemen Stok Obat Menggunakan Metode Fifo (First In First Out). Jurnal Universitas Teknologi Yogyakarta.

Palupi, D.E., 2015. Sistem Informasi Akuntansi Persediaan Barang Dengan Metode Fifo (Studi Kasus Pada De Kosmo Factory Outlet). Jurnal Sekolah Tinggi Elektronika Dan Komputer Semarang.

Pranggono, N.M., Irawati, T. \& Laksito, W., 2016. Sistem Informasi Persediaan Barang Secara Multiuser Pada Apotik Kinasih Bulu Sukoharjo Dengan Metode Rata-Rata Bergerak. Jurnal STMIK Sinar Nusantara Surakarta, ISSN : 1693 - 1173 .

Pressman, R.S., 2010. Rekayasa Perangkat Lunak. Yogyakarta: Andi.

Pressman, R.S., 2012. Rekayasa Perangkat Lunak: Pendekatan Praktisi Buku I. Yogyakarta: Andi.

Rangkuti, F., 2005. Manajemen Persediaan Aplikasi di Bidang Bisnis. Jakarta: Erlangga.

Rosa, A.S. \& Shalahuddin, M., 2013. Rekayasa Perangkat Lunak Terstruktur dan Berorientasi Objek. Bandung: Informatika.

Sadeli, M., 2014. Aplikasi Bisnis dengan PHP dan MySQL. Palembang: Maxikom.

Sartono, A., 2010. Manjemen Keuangan Teori dan Aplikasi. Yogyakarta: BPFE.

Simamora, H., 2000. Akuntansi Basis Pengambilan Keputusan. Jakarta: Salemba Empat.

Sugiyono, 2011. Metode Penelitian Kombinasi (Mixed Methods). Bandung: Alfabeta.

Sugiyono, 2014. Metode Penelitian Pendidikan Pendekatan Kuantitatif, Kualitatif, dan R\&D. Bandung: Alfabeta.

Sutabri, T., 2012. Konsep Sistem Informasi. Yogyakarta: Andi Publisher.

Syakur, A.S., 2009. Akuntansi Keuangan Menengah Dalam Perspektif Luas. Jakarta: AV Publisher. 